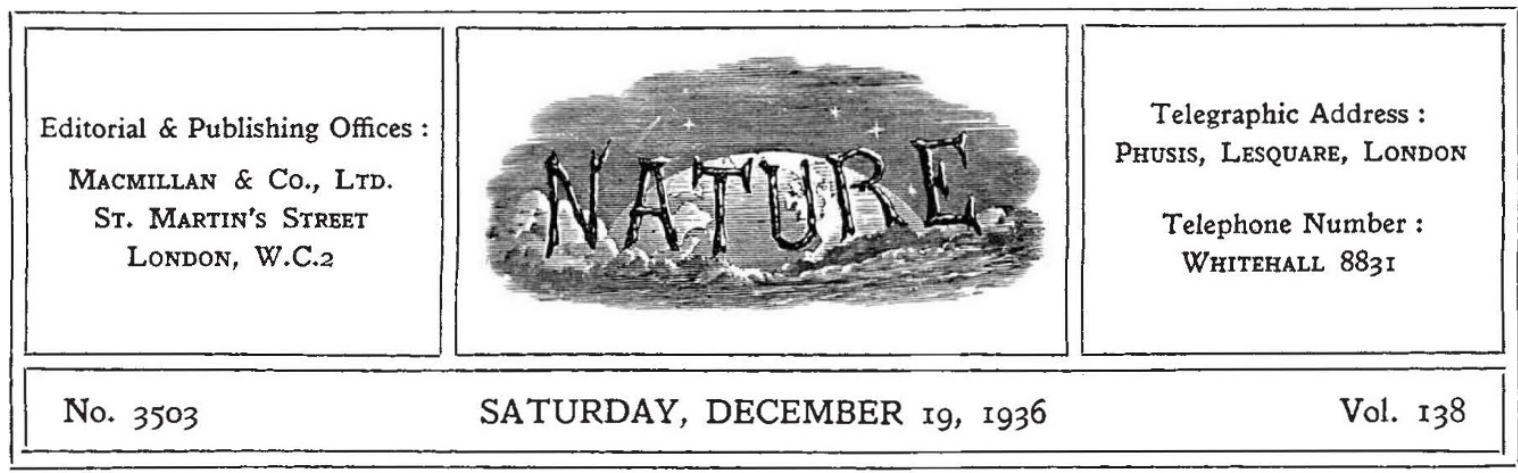

\title{
Kingship and Kinship
}

$\mathrm{F}$ ROM him to whom much has been given, much shall be required. The moving words with which on the night of December 11 Prince Edward took leave of his people, his subjects no longer, closed a great career of public usefulness, upon which strong hope for the future had been founded. That valediction, however, stands for far more than that. It marks the end of an epoch in which the relationship of the British Crown to the people has been peculiarly intimate and personal. It is true that the events of that momentous period of stress, which opened on December 2, have left the monarchy unshaken; it is even strengthened; but it would be idle to claim that it is unchanged. With the proclamation of His Majesty King George VI on December 12, a new era begins.

In the history of kingship, as has been shown by recent research, the well-being and virility of the king is identified with the prosperity and fertility of land and people. It is not without significance, perhaps, that it is precisely among the descendants of those peoples who relied most on the qualities of their king or chief as leader, the conquering Nordic peoples, to use a convenient descriptive nomenclature, that kingship has been most enduring. Yet if the king is the fount of honour, the leader in war, and in peace the source of law and order, as well as the supreme overlord of land and people, it is not in the sense of absolute monarchy in which Louis XIV claimed l'état, c'est moi. Britain, fortunate in this as in other matters affecting the liberty of its people, early won affirmation of the principle, which had governed the early kingship-even as now it regulates the powers of the paramount chief in parts of tribal Africa-that the king holds power in virtue of a trusteeship for his people and must rule in concurrence with his and their councillors. It is this principle, with many vicissitudes and obscurations, which runs through the weft of British constitutional development and the growth of selfconsciousness in the people. It attained the full measure of imperial democracy in the Statute of Westminster of 1931, and first found opportunity for full expression, bitter though it was, in the tragedy of December 1936.

Events which in other days might well have given rise to revolution have passed without disturbance. That it has been possible for a great and unanimous volume of public opinion to crystallize without delay over the vast distances of the Fmpire is due in no small measure to the resources which science has placed at the disposal of our rulers in cable and wireless, aided by the newspaper press. It marks a new phase in the growth of democracy. But also it imposes a special responsibility on the new monarch.

It has been pointed out again and again in recent years that the King-Emperor is now the only link which binds together the independent nations which form the British Commonwealth. The new monarch has been acclaimed as "the people's King". This title confers upon him a great trust, but it lays upon him also a heavy burden, as guardian of the honour and integrity of his people. By his personal character and his sense of responsibility he will win the loyal support of his subjects in helping him to bear it. Now that the British Commonwealth of Nations has shown that it is no loose aggregate, but a closely knit unity, if of diverse parts, each of those parts will look to its king as its special representative, for whose services as arbiter, and as the interpreter of the constituent elements one to another, it will be prepared to pay with ever-ready loyalty. 